\title{
N. S. Galgano, I precetti della dea. Non essere e contraddizione in Parmenide di Elea, Diogene Multimedia, Bologna 2017. ISBN 978-8893630863
}

\author{
Marco Montagnino*
}

«Parmenides has invented the notion of not-being» (p. 163). The interesting and singular investigation of Nicola Galgano moves from this assumption and opens by declaring the need to deepen the Parmenides' notion of «non-being» to reach the roots of that crucial opposition between «being» and «not-being» from which the so-called Eleatic aporia has arisen (p. 12). The explicit intent of the author is to «fill with his study the gap of detailed research on the theme of not-being in Parmenides», going beyond the logicallinguistic frame and facing directly («francamente») the theme's philosophical dimension (p. 14).

The first chapter («Introduzione alla nozione di non essere») starts from the assumption that the notion of «not-being» is «genuinely transcendent» in as much as it is «a creation of the human mind itself», which appeared for the first time with Parmenides (p. 17). Starting from Melissus, however, this notion has been misunderstood and progressively hypostatized by philosophers (and theologians) until one reaches Heidegger who considered «not-being a concrete alternative to being» (p. 18).

In this chapter one misses a general survey of interpretations of the Parmenidean notion of «not-being» in later philosophy as well as in the history of philosophy. ${ }^{1}$ Galgano

\footnotetext{
* I would like to thank Prof. Maria Michela Sassi, from Università degli studi di Pisa (ITA), and Prof. Rose Cherubin, from George Mason University (USA), for accurately revising the English version of the manuscript and for giving me useful suggestions in order not to lose in translation my argumentative purposes.

${ }^{1}$ Although an exhaustive survey would not be possible, given that practically anyone who wrote a monograph on Parmenides addressed the notion of not being, still the paragraph dedicated to it seems too concise (pp. 20-23).
} 
refers to a work by Arnold Hermann ${ }^{2}$, which calls for a more detailed comparison, only in the context of a detailed discussion (on p. 140 n. 145 and 163 n. 164). Even more interesting would have been a comparison with a little known study by Colombo, The primacy of nothing and the origins of metaphysics ${ }^{3}$, that Galgano mentions as «the first text dedicated to non-being of Parmenides" (p. 14).

In presenting his investigative method, the A. specifies that the figure Parmenides that emerges from his analysis is an unprecedented «scholar of the mind, what we would now call a psychologist» (p. 26) and accordingly proposes to reconstruct the psychological vocabulary contained in the poem, «hitherto dispersed» (p. 26). To that end, he integrates his philological and linguistic analysis into Plato's philosophical interpretative context. Galgano trusts Plato's testimony on Parmenides' thought above all the other ones because «not only Plato is the oldest of the authors who cite Parmenides but given his philosophical greatness he cannot fail to have understood Parmenides' message better» (pp. 26-27). ${ }^{4}$ This is a very clear "choice of field" that is not widely shared today and that therefore would have required a more lively dialogue with the other scholars considered in the book. ${ }^{5}$ But it must be recognized that the Author develops his argument in a manner consistent with his assumptions.

In the second chapter («Parmenide psicologo - Prima parte»), Galgano specifies that in making use of the term 'psychology' he distances himself from the meaning of psyche as "soul" and refers to that of mind because he states that Parmenides poem «is a poem of the mind, for the mind, and on the mind» (p. 39). He also remarks that «there are almost no studies on psychology in Parmenides' work» (p. 34), which was not even taken

${ }^{2}$ A. Hermann, What are the semata of "What is not" in Parmenides' Poem?, in L. Ruggiu - C. Natali (eds.), Ontologia scienza mito. Per una nuova lettura di Parmenide, Milano-Udine 2011, pp. 135-171.

${ }^{3}$ A. Colombo, Il primato del nulla e le origini della metafísica, Milano 1972.

${ }^{4}$ Concept reiterated on p. 28 (where the Sophist's testimony is valued), on p. 109 and on p. 201 (on the need of the scholars to free oneself from the «post-Platonic cultural layers ...»).

5 E.g. A. Hermann, Parricide or Heir? Plato's Uncertain Relationship to Parmenides, In Parmenides, 'Venerable and Awesome' (Plato, Theaetetus 183e), edited by Cordero, Néstor-Luis, 147-165. Las Vegas: Parmenides Publishing; D. O'Brien, Parmenides and Plato on What Is Not, in The Winged Chariot. Collected Essays on Plato and Platonism in Honour of L.M. De Rijk, Leiden

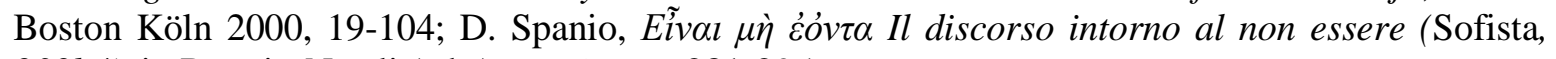
239b4), in Ruggiu-Natali (eds.), op.cit., pp. 281-295. 
into account by the «philosophy of mind». Conversely, Galgano thinks that only taking Parmenides as a «true psychologist (perhaps "cognitivist") who is worried about the «impossibility of thinking about non-being» (p. 33) allows us to understand how he came to discover «the contradictory nature of non-being» (la contraddittorietà del non essere»; ibid.).

In this chapter Galgano highlights the Parmenidean terms that would refer to the concept of «mind» that emerge in particular from the analysis of fr. 1, 2, 6 and 7. While declaring himself highly skeptical about the theoretical value of the poem's proem (judged as a «fantasy» work, p. 42), the A. finds in the first verse of it «the great theme of the poem, the mind», and locates in the word thymos «the key to follow the didactic path that Parmenides, through the goddess' voice, will offer to his reader» (p. 38). Then Galgano skips the first 27 verses of the proem and goes straight to the analyses of the expression aletheies eukykleos ${ }^{6}$ atremes ètor $(\mathrm{B} 1,29)$, with the conclusion that ètor «must not be translated by heart, but it should be taken in the sense of "seat of the capacity of reasoning" [«sede delle capacità di raziocinio»], that is, mind» (p. 50). Consequently we can translate the whole expression as «the firm mind given by the well-connected truth [«la mente salda data dalla verità ben connessa»]» (p. 52). ${ }^{7}$

According to the A. the «huge discovery» of Parmenides is that a person can be persuaded that any belief or opinion about the world can be a bit of valid knowledge, even though «being convinced of something does not make this something true» (p. 56). Parmenides would therefore have deduced that what we need is not new knowledge but a way «to certify the truth», something prior to the act of knowing and related to our minds functions. The «precepts of the Goddess» to which the title refers are therefore the methodological directives that lead man to distinguish persuasive speeches according to the truth from those that persuade in an unreliable way (pp. $55 \mathrm{ff}$.).

In other words, the ignorance of the mortal eidotes ouden, in Parmenides' view, would lie in believing the explanations of the world that they «invent and fantastically

\footnotetext{
${ }^{6}$ Galgano prefers this lectio to the other ones, which he analyses anyway.

7 Regarding the term atremes, because Galgano gives importance to this concept in his interpretation, it would have been interesting to have a more in-depth comparison between the attestation of fr. 1, widely discussed by the Author, and that of fr, 8 , v. 4, almost ignored (there is only a hint on p. 146).
} 
create» with «subjective formulations», and which are consolidated over time in the form of myths (which are therefore «mere fantasy»). But these myths generate «false persuasions» because they are precisely the work of men and not of gods', because the gods only tell the truth (so the Author explains Parmenides' recourse to the divine in the poem). According to Galgano, therefore, «the recurring theme of the poem is not so much the affirmation of "being" <...> but the distinction between a true and an untrue persuasion [una persuasione vera e una persuasione non vera]» (p. 75), and he concludes that «if you want to divide the poem into two parts, these are true persuasion and untrue persuasion, not truth and opinion (p. 102, n. 109).

On p. 58 comes into play the nous, third but fundamental term of the psychological vocabulary reconstructed by Galgano, which the Author (detaching himself from any other scholar) proposes to conceive as the complex of «cognitive operations of the mind» («operazioni cognitive della mente»; p. 64), which can be correct or incorrect depending on whether you rely on the «precepts of the goddess» or not. ${ }^{8}$ In other words, human nous on its own is not enough to understand the truth of reality, as is shown, among other things, by its being linked to the concept of amēchanie, this being interpreted as an inability not of man but «of the human mind » (pp. 76 ff.). After Parmenides' «perfect psychological analysis» humans are equipped with sensory organs «but without a certain instrument [precisely the méchanē] in their mind it is as if they did not have them» and therefore they work with «errant cognitive operations (plakton noon)» (p. 79). Ultimately, it is the «psychichological lack» of this mēchanē («risorsa», «strumento mentale») ${ }^{9}$ which prevents mortals from distinguishing «being» and «non-being» (p. 80). Conversely, Parmenides’

\footnotetext{
${ }^{8}$ We believe that, for sake of a smoother reading, the Greek term nous could have been left untranslated once the Author had explained that the word as «cognitive operations of the mind». Furthermore, in the philosophical perspective that the text proposes, there is a lack of consideration of the interpretations of the concept of nous by Heidegger and Gadamer, which could have proved fruitful precisely in relation to the thesis that the subject of thought and its object «belong in the same order as physis» (p. 188).

${ }^{9}$ Again, for sake of a smoother reading, the term could have been left untranslated, because its semantic complexity is not well rendered by the concepts «resource», «tool» or «artifice». Plato also uses this concept in Philebus (23 b7) to refer to the cognitive process of his dialectic and $\mathrm{H}$. G. Gadamer, Philosophical Studies, Genoa 1983, 109, translates it as "organization" (which perhaps render its complexity better).
} 
«the man who knows» is «the man with such resource [«l'uomo con la risorsa»]» (p. 9293).

The program of the Parmenides' goddess is therefore to teach (starting from fr. 2) this «artificial tool that enables one to fill the gap of mortals», that is the mental habit that leads us to suppose our beliefs about the world to be true (the ethos polypeiron) which has consolidated itself socially. Following the teachings of Xenophanes ${ }^{10}$, Parmenides describes «the cultural process of configuring the peoples' forma mentis (phyla, B6, 7)» and «makes a criticism of the traditional way to think» inherent in mythical-religious thought (pp. 85-86). ${ }^{11}$

With the third chapter («Il metodo») Galgano hypothesizes that Parmenides proceeded through a sort of self-analysis of the «behaviour» of the mind (pp. 95-96), which would have led him to «resort to something extra- mental» to know if his beliefs were true or not. The author explains that Parmenides, after having «annihilated» («annientato») everything by denying it with his reflection on non-being (p. 130), aware of the impossibility of the absolute anihilation, finally "re-emerge", we could say, «to the normal flow of his thoughts ... with a cry: it is!». A «cry» that is not like an eureka! exclamation but «the expression of the pre-syntactic and pre-logical experience » of the existence (ibid.), in the same way that the «ouch!» that we cry when we get hurt means the pain even before we conceive that we have hurt ourselves. This is the reason why, when asked about the subject of the estin in verses B2, 3-4, Galgano replies that «the estin is prior to the syntactic articulation, therefore it is subject, predicate and object of itself» (p. 131).

Therefore Parmenides distinguishes two types of persuasion, as we have already seen: «true persuasion» (peithō), which the A. proposes as a more fitting definition of the so-called first part of the poem, and the «untrue persuasion», the «'opinions of mortals', in which there is no pistis alēthēs», identified by Galgano as the object of the second part (pp. 102-104). Therefore «the alêtheia of which Parmenides speaks» would be «that of

10 Even in this case Galgano relies exclusively on Plato's interpretation (p. 29) and poses as «settled» (p. 73) the relationship of discipleship between Parmenides and Xenophanes which is instead controversial (for an overview of the matter see M.M. Sassi, Styles of thought to Elea. For a contextualization of the beginnings of "philosophy" in Velia. Acts of the 45th Conference of Studies on Magna Grecia, Taranto 2006, pp. 95-114).

${ }^{11}$ The Author excludes (p. 169 no. 170) that Parmenides turns against the cosmological thought of Ionians and Pythagoreans: an exclusion not unanimously shared. 
persuasion» («quella propria della persuasione»; p. 102): a definitely strong thesis, which however could hardly be "classified" as ontological, unless it is conceived in the context of Heidegger's thesis that language is the house of being - but this would not seem to be the case here.

One would expect that Parmenides' path to alètheia starts from the absoluteness of «being», but the Author "surprises us" by assuming that it starts from the awareness of the impossibility of «non-being». «Parmenides uses negation grammatically, but also gnoseologically and epistemologically» (p. 111): thinking over the «absolute total nonbeing» (p. 129), perhaps on the basis of his Pythagorean education (p. 116), Parmenides would have come to the awareness that the «thinking about non-being» is just impossible and therefore you cannot even say it (p. 120). From this unspeakableness («indicibilità») derives the fundamental intrinsic contradiction of our way of thinking: «when I say 'the square triangle is a geometric figure' I can believe that I am saying something coherent and I might be able to make someone believe that my statement is true. However, 'square triangle' is an impossible entity (a non-entity, in Parmenidean language, to mē eon), as well as it has no epistemic sense, so this statement lacks meaning» because it contradicts reality and so it has no «ontological foundation» (P. 123), as «the man with the resource [«l'uomo con la risorsa»]» knows.

However, when Galgano speaks of the impossibility of saying «square triangle» because «by definition the essence of the triangle excludes that of the square» (p. 126), we do not need to resort to Wittgenstein to point out that the question, in these terms, is not ontological but logical-linguistic. A critical issue that we underlined above with regard to the concept of «true persuasion» and which characterizes the whole chapter.

In chapter 4 («Discussione e applicazione del metodo»), the Author goes on to analyse fragments 6,7 and 8, and suggests that from the irreconcilability and divergence of the two paths of research, Parmenides would have derived not only the principle of the excluded middle, but the ontological foundation for it, so that «there is not a third possibility between (real) being and nothingness» (p. 157). But «nothingness» is only an illusion («virtualità») of the mind (p. 142), so it is confirmed the conclusion that there is no alternative to the way of «being». 
This chapter raises perplexity in that Galgano describes Parmenides' ontology as follows: «the entities of the sensitive world, in their ontological status, are no different, as entities (not as sensitive), from intelligible entities and as well as after operation $2+3=5$ we continue to have a 2, a 3 and a 5 , so even in an operation boards + nails $=$ bed, once the operation is completed we will continue to have boards, nails and bed, as before, although before the 'notion of existence' (the noema, Parmenides would say) of that specific bed was not yet present». ${ }^{12}$

What does the Author mean when he speaks of the difference in «ontological status» of entities as «sensible» and as «intelligible»? Galgano hasn't spoken so far about differences between the sensible world and the intelligible world, nor of an ontological condition that would distinguish a sensible dimension entity itself (which entity then?) opposed to its (are we talking about the same entity?) intelligible dimension. Even the equation «Parmenidean noema» = «'notion of existence'» seems to pop up here. In general one gets the impression of being in front of an ante litteram version of Plato's doctrine of ideas and has a feeling that the Author has let himself be seduced a little too much by the Platonic reading of Parmenides. If Galgano assumes that the text authorizes this reading (a highly respectable hypothesis which could quite rightly be part of the wider literature that makes Parmenides the initiator of metaphysics) he probably should have argued the hypothesis more accurately.

Moreover, in chapter 5 («Il non essere in Parmenide») we are still facing an "exquisitely" Platonic Parmenides. In fact, we read that to conceptualize the notion of «non-being» Parmenides followed a path from «denial of physical entities» to «negation of thought entities» (p. 164) because the problem of the knowledge of «being» lies in the human cognitive functions apparatus (pp. $168 \mathrm{ff}$.), so that at the end of this route only mathematical entities can be considered truly Parmenidean entities, «since they were not and will not be, they simply are» (p. 171).

\footnotetext{
12 «Gli enti del mondo sensibile, nel loro status ontologico, non sono differenti, in quanto enti (non in quanto sensibili), dagli enti intelligibili e così come dopo un'operazione $2+3=5$ si continua ad avere un 2 , un 3 e un 5 , così anche in un operazione tavole + chiodi = letto, una volta conclusa l'operazione si continuerà ad avere tavole, chiodi e letto, così come prima, sebbene prima non fosse ancora presente la 'nozione di esistenza' (il noema, direbbe Parmenide) di quel letto specifico» (pp. 159-160).
} 
In the conclusions of the chapter, quoting Rossetti ${ }^{13}$, Galgano leads to the extreme consequences these premises and affirms that Parmenides and the other Eleatics not only «failed to propose cosmologies in consonance with their precepts» - something that Plato also seems to think, moreover - but «starting from the Parmenidean precepts, no one has succeeded in proposing a positive cosmology [«una cosmologia positiva»] to date» (p. 171).

Furthermore, according to Galgano, while for the subject it is impossible to grasp the nature of the negation within our cognitive structure, on the other hand trying to think beyond our cognitive structure is as useless as «the attempts made by a blind man to understand the world visually» (p. 177). Even in this case, however, we note that Parmenides certainly could not have conceived «entities of thought» ontologically separated from physical ones (neither could the Pythagoreans do that). However, these considerations seem to be in contrast with the general idea set out above in the book and taken up again in the next chapter, according to which it seems that man actually has a chance of truly knowing «being», and that this possibility is given precisely by the mēchane provided by the goddess with her precepts.

Another central thesis of the book arises here: Parmenides did not base his ontology on the opposition «being» / «not-being» but on a «molto più "principale"» opposition «than the principle of non-contradiction», that is the «incompatibility [«incompatibilità»] between non and being» (p. 166; Author's bold), «where the non is a behaviour [«comportamento»] of thought, that is, the behaviour of negation, and being is the being of the world, the entities, the panta: therefore being cannot be denied» (p. 200). Not only we can't deny the absolute «being», but «any single being ${ }^{14}$, even what we judged - in one way or another, rightly or wrongly - to be deniable» (p. 166). The recourse to the concept of «incompatibility» seems to imply a different «ontological status», and therefore a transcendence, between «being» and «thought», but it is not clear whether the A. intends this implication or not.

\footnotetext{
${ }^{13}$ L. Rossetti, Perchè Parmênide non rinunciò alla seconda sezione del poema, mentre i suoi allievi diretti lo fecero?, in N.L. Cordero, Eleatica 2006: Parmenide scienziato?, L. Rossetti, F. Marcacci (eds.), Sankt Augustin 2008, pp. 133-141.

${ }^{14}$ «Parmenides, from the beginning, speaks of all things (panta, 1.28), in the plural», not only of the universal being (p. 171).
} 
However, Galgano goes on to say that Parmenides «imposes an existential axiological isonomy [«isonomia assiologica esistenziale»]: all beings have the same existential value», that is, both «what we judge as meritorious of eternity» and even «what we judge that doesn't deserve eternity» can both be eternal, and this «oblig[es] us to think about existence (being) in a completely different world order». A world in which we can conceive that nothing changes because «what seems to be the mutation of an entity is just the presence of two different entities [ciò che sembra che sia la mutazione di un ente non è se non la presenza di due enti diversi]» which «are positivity [«positività»] and, as positivity, they do not accept negation» because to deny a positive would be to affirm «an ontological impossibility [un'impossibilità ontologica]» (pp. 166-168).

Such an interpretative proposal recalls - right from the use of the concepts of «positivity» and «eternity» - the radical (and controversial) reinterpretation of Parmenides that Severino proposed in 1964, in his work Ritornare a Parmenide. ${ }^{15}$ We do not want to suggest a connection between the two interpretations, both because Galgano's judgment on Severino's essay is quite severe ${ }^{16}$ and because their philosophical languages are clearly different from each other, but we note that a more careful comparison with Severino's philosophical interpretation of Parmenides poem would certainly have benefited Galgano's argument.

Already from the title («Parmenide psicologo - Parte 2»), the sixth chapter looks like a development of the previous discourse on Parmenides as psychologist. Galgano highlights here how for the Eleatic the subject of thought and its object «belong to the same

${ }^{15}$ E. Severino writes, in Ritornare a Parmenide, «Rivista di filosofia neo-scolastica», 56, 1964: «The immutability of being is posed by Parmenides through this sole consideration, which touches the bottom of the truth of being: if being becomes (is generated, is corrupted) it is not, (ouk esti). And this must be said of being as such, that is, whether you consider it as the totality of the positive, or that you consider it as this poor trivial thing that is this pen. [...] Which means for us that everything, however despicable [Severino is quoting the Socrates of Plato's Parmenides], if it is one thing, is eternal. This sheet, this pen, this room, these colours and sounds and shades and shadows of things and the soul are eternal...» (p. 146; translation by us). And on pp. 174-175 he writes: «... everything is eternal in that it is a positive».

16 Galgano cites Severino's article only to emphasize that he «only takes inspiration from Parmenidean suggestions to develop his philosophy» but he is not «an exegete or a scholar of Parmenides». (pp. 166-67 n. 167). It is thus even more curious that Galgano too, like Severino, relies on the criticism that Parmenides, according to Plato's narration, addresses to Socrates who didn't think it possible that the most humble things (Severino uses the word «spregevoli», that we translated with «despicable») could enjoy eternity (Parm. 130 ce). 
order of the physis and it is this belonging that allows the possibility of knowing» (p. 188). Here however it is not clear what the A. means by separating subject and object of thought and if the claimed «same order of the physis» has an ontological status or not.

This chapter includes an accurate analysis of fragment 8, in which Parmenides would show how the goddess' precepts («the resource», as it has been defined) translate into the discursive practice of true persuasion. Another topic of the chapter is the «psychological» reading of fr. 4, that is presented as «the first description of the process of abstraction of western culture» (p. 192). The common man sees things as if they are separate from each other: when he thinks «book», he gets «an idea as if the book was surrounded by nothing». «The man with the resource», instead, through «the cognitive operations of the mind» (the nous) sees, «together with the book that the common mind sees as present, also the table, the cup and other things, which, despite appearing absent, in fact, actually they are present» (p. 192). What you miss in this chapter is an analysis of the fr. 16 which Galgano doesn't expressly take into account not only because he regards it very obscure but because it «presents a medical theory of thought ... or the association of sensations with the mind ... and not a behaviour of the mind» (p. 194). ${ }^{17}$

In the last chapter - which takes up the title of the book - the A. reiterates that for Parmenides «on the one hand there is a structure of the world that is, so to speak, objective and, on the other, there is a subjective understanding of this structure» (p. 198) and clarifies (p. 200) that the precepts of the goddess disseminated throughout the poem allow us to

\footnotetext{
${ }^{17}$ We would like to point out that it would have been appropriate to dwell also on this fragment as it presents, such as the A. himself underlines, «an evident psychological vocabulary», and focuses on the concept of nous. Neither is it clear why a psychological reading, especially a cognitive one like that of Galgano, couldn't be compatible with a «medical theory of thought» or the «association of sensations with the mind» (as the A. describes the content of B16). On the fact that the fragment contains a mere medical or physiological theory (always in the medical sense of the term), there is no unanimity among scholars. M.M. Sassi, "Parmenides and Empedocles on Krasis and Knowledge", «Apeiron», 49/4 (2015), pp. 451-469, proposes the reasonable hypothesis that Parmenides may have been the first «to link the issue of cognition to the proportion of elements in the mixture constituting the body» (p. 461) not in a medical direction - «Parmenides is not so much interested in the problem of health and disease ... [and in] the interaction of the individual body with a certain food and regimen» (p. 462) - but «to explain the cognitive phenomena by rooting them in the physical structure of the subject as well as in his or her relation to the things» (p. 465). Therefore we believe it would have been interesting (and we hope that the A. will do this in the future) to try to integrate also the fragment 16 in the interpretative framework outlined.
} 
recognize the «structure of the world» in its truth (or rather in its true persuasiveness, in Galgano's terms $)^{18}$.

From the whole work there emerges a dualistic view of the Parmenidean ontology. The A. doesn't go so far as to suggest that it is a metaphysics. On the contrary, on several occasions he underlines that what Parmenides has in mind is a physical cosmology even if, so to speak, an "unfinished" one. But Galgano nonetheless proposes an undefined hiatus, if not between subject and object, then between subject / object on one side and thought on the other, as if the latter were an external "medium", which "correct" functioning depends on the punctual application of the divine precepts: but (this is the paradox) this application however would inevitably lead to denying the very possibility of a cosmology (so on p. 171).

In short, it is not clear whether for Galgano Parmenides has finally found a way to understand reality in its truth or has concluded that such an understanding is impossible because of an irremediable gap between the sensible world and the intelligible one. But in this case we would find ourselves faced with a variation on the theme of the traditional interpretation of the poem, where again the problem of the distinction between the first and second part of the poem would arise. One could think that perhaps the Author's intentions are precisely these: to leave his investigation open to further developments on «Parmenidean meontology» (p. 178), to which perhaps he is already dedicating his studies, and which we hope to be able to read soon.

Let us add a few last considerations. By translating the opposition «being» / «notbeing» into the contradiction between the cognitive dimension of «not» and the ontological dimension of «being» - thereby presupposing the cognitive dimension as a «border region of the ontology itself» ( $\mathrm{p}$ 175) - Galgano engages theoretical questions (far from being resolved) which are typical not only of the philosophy of language but also of philosophical hermeneutics, cognitive sciences and the so-called philosophy of mind: subject / object, mind / world, scheme / content, etc. ...

\footnotetext{
${ }^{18}$ Galgano (p. 213) defines three fundamental «precepts of the goddess»: the one that defines what contradiction is (the principle of contradiction), the one that refers to thinking and saying (the logical principle of non-contradiction), and the one that refers to entities of the world and their order (the ontological principle). And they all flow into the only fundamental precept: «it is impossible to deny being (non-being it's impossible)» (p. 200).
} 
Galgano's hermeneutic operation (certainly complex and intriguing) calls into question such a plurality of interpretative levels that it would have perhaps required a greater clarity in the use of certain terms or expressions. We are talking e.g. about the passage when the A. says that Parmenides «breaks» with the «naive cognitive realism [realismo ingenuo cognitivo]» from which his contemporaries learned or the previous ones could not come out of (p. 198); or when he writes that Parmenides would have deduced the notion of «non-being» from the reflection on the «disproportion between the content (semantics) and the receptacle (the word), between the meaning and the signifier» ${ }^{19}$; or, further, when he stigmatizes logical studies on Parmenides' thought by writing that these, «together with non-being, have embarked without hesitation on unusual adventures between strange and often even terrifying worlds» (p. 14).

In summary, Galgano's thesis is that the doctrine about which scholars and philosophers have been struggling for 2500 years would be a sort of residual product of what was the real and most important discovery of Parmenides: the «impossible relationship between [the cognitive dimension of] not and [the ontological dimension of] being» (p. 178). It is from this reflection that Parmenides had then deduced the absolute being on which we "got bogged down" starting from «a certain orientation of the ancient Germanic school of history of philosophy [which] has overshadowed [the notion of not being] in favour of the notion of being» (p. 109). Certainly a stimulating thesis, at times "provocative" but never careless, and one that provides very interesting ideas for Parmenides scholars even if one does not agree with it.

Marco Montagnino

Università di Palermo

\footnotetext{
${ }^{19}$ «La sproporzione fra il contenuto (la semantica) e il recipiente (la parola), fra il significato e il significante» (p. 127).
} 